\title{
Diagnostic significance of nitric oxide concentrations in exhaled air from the airways in allergic rhinitis patients
}

\author{
Anna Kłak, Edyta Krzych-Fałta, Bolesław K. Samoliński, Marta Zalewska \\ Department of Prevention of Environmental Hazards and Allergology, Medical University of Warsaw, Warsaw, Poland \\ Adv Dermatol Allergol 2016; XXXIII (2): 87-95 \\ DOI: $10.5114 / a d a .2016 .59147$
}

\begin{abstract}
Introduction: The effect of nitric oxide (NO) on the human body is very important due its physiological regulation of the following functions of airways: modulation of ciliary movement and maintenance of sterility in sinuses.

Aim: To evaluate the diagnostic significance of NO concentrations in exhaled air from the upper and lower airways in patients diagnosed with allergic rhinitis (AR).

Material and methods: The subjects included in the study were a group of 30 people diagnosed with sensitivity to environmental allergens and a control group consisting of 30 healthy subjects. The measurement of NO in the air exhaled from the lower and upper airways was performed using an on-line method by means of Restricted Exhaled Breath (REB), as well as using the measurement procedure (chemiluminescence) set out in the guidelines prepared in 2005 by the American Thoracic Society and the European Respiratory Society.

Results: In the late phase of the allergic reaction, higher values of the level of exhaled NO concentration from the lower airways were observed in the groups of subjects up to the threshold values of $25.17 \mathrm{ppb}$ in the group of subjects with year-round allergic rhinitis and $21.78 \mathrm{ppb}$ in the group with diagnosed seasonal allergic rhinitis. The difference in the concentration of NO exhaled from the lungs between the test group and the control group in the $4^{\text {th }} \mathrm{h}$ of the test was statistically significant $(p=0.045)$.

Conclusions: Exhaled NO should be considered as a marker of airway inflammation. It plays an important role in the differential diagnosis of allergy.
\end{abstract}

Key words: nitric oxide, upper and lower airways, allergic rhinitis, breathing.

\section{Introduction}

As long as 20 years ago, Zawadzki and Furgchott described an impermanent substance referred to as endothelium-derived relaxing factor (EDRF), which was later characterised as nitric oxide (NO) [1, 2]. The effect of NO on the human body is very important due its physiological regulation of the following functions of airways: modulation of ciliary movement and maintenance of sterility in sinuses. Nitric oxide was identified in the upper airways by Alving et al. [3]. Subsequent research showed that healthy people exhale NO mainly from their upper airways and only insignificantly from their lower airways and lungs [4]. The high local concentration of NO in the upper airways and the nasal sinuses may provide protection against airborne infection agents [4]. The NO found in the airways may be the first line of defence against pathogens, preventing them from penetrating the mucous membrane [4].
The level of NO in the nasal sinuses is a few times higher than in the nose. It is assumed that the sinuses are the main producer of NO in the airways [5, 6].

$A$ vast body of epidemiological research proves that allergic rhinitis (AR) is a risk factor in the development of asthma [7-9]. In the early years of a person's life, ALRH symptoms are often a precursor of the development of asthma in the future [7]. It has been proved that the risk of asthma is three times higher in ALRH patients compared to the control group [8]. The inflammatory process plays a key role in the pathogenesis of asthma and ALRH. Inflammatory cells identified in induced sputum are found in the airways of asthma patients and in the bronchia of patients with seasonal allergic rhinitis (seasonal AR - SAR) [10]. It has been proved that fractional exhaled nitric oxide (FENO) in seasonal ALRH patients before the pollen season compared to the control group of healthy volunteer sub-

Address for correspondence: Anna Kłak MSc, Department of Prevention of Environmental Hazards and Allergology, Medical University of Warsaw, 1A Banacha St, 02-097 Warsaw, Poland, phone: +48 22599 20 39, e-mail: anna.klak@wum.edu.pl Received: 12.05.2014, accepted: 23.09.2014. 
jects without symptoms of atopic lung disease and in patients with non-allergic rhinitis is higher [11]. The increase in FENO in patients with allergic rhinitis may be linked to a high risk of asthma [12].

\section{Aim}

The aim of the study was to assess the diagnostic importance of the concentration of NO in the air exhaled from the upper airways and lower airways in patients diagnosed with (year-round and seasonal) allergic rhinitis. The specific aim of the study was to determine the average level of NO exhaled from the nose and lungs in three phases: an initial phase, an early phase (in the $30^{\text {th }}$ min of the test) and a late phase (in the $4^{\text {th }} \mathrm{h}$ of the test) and to identify patients' subjective sensations during the test by means of a visual analogue scale (VAS).

\section{Material and methods}

\section{Test group}

The subjects included in the study were a group of 60 people (30 patients and 30 healthy subjects as a control group). The test group consisted of 16 men and 14 women diagnosed with sensitivity to environmental allergens (Dermatophagoides farinae, Alternaria tenuis grasses/corn, Dermatophagoides pteronyssinus). A total of 15 allergens were used in the test (i.e. mites (8), grasses/corn (5), moulds (2)). Twelve patients with chronic allergic rhinitis (ALRH) and 18 patients diagnosed with seasonal allergic rhinitis were qualified for the test (Table 1). The average age in the test group was 27.33 years (24.25 for the chronic ALRH patients; standard deviation: 3.42; 29.39 for the seasonal ALRH patients, standard deviation: 6.001). The average body mass index (BMI) was 23.9 (22.992 for the chronic ALRH patients: 24.650 for the seasonal ALRH patients). The difference in BMI between the test group and the control group was not statistically significant $(p=0.585)$. A statistically significant correla- tion between the age of the subjects in the test group and those in the control group was found ( $p=0.033)$.

\section{Test method}

The test method was based on measuring "subjective" sensations using a visual analogue scale and techniques for measuring the concentration of NO in the air exhaled from the respiratory system.

\section{Inclusion and exclusion criteria}

Subjects were qualified as allergic rhinitis patients if they met the following criteria:

- the subject has experienced sensitivity to a particular allergen for at least 3 years;

- the subject has had positive skin tests measuring sensitivity to environmental allergens (the average size of an allergic blister: $8.9 \mathrm{~mm}$ for patients with seasonal ALRH and 11 for patients with year-round ALRH), - nasal patency maintained.

The occurrence of the following factors was the basis for excluding a patient from the test:

- nasal polyps,

- bronchial asthma,

- severe infection of the airways within 4 weeks before the test,

- at least 6 weeks from the last occurrence of an allergic rhinitis symptom,

- vaccination within 1 week before the test,

- inflammation of the frontal and nasal sinuses,

- high content of nitramines in the person's diet.

\section{Nitric oxide measurement}

In order to measure the concentration of $\mathrm{NO}$ in the air exhaled from the lower and upper airways, three measurements were taken: in the initial phase, in the early phase (in the $30^{\text {th }}$ min of the test), and in the late phase (in the $4^{\text {th }} \mathrm{h}$ of the test). Figure 1 shows the structure of the test.

Table 1. Average levels of the measured values height, weight, BMI and age in the groups of patients with allergic rhinitis (ALRH)

\begin{tabular}{|c|c|c|c|c|c|}
\hline $\begin{array}{l}\text { Average levels } \\
\text { of measured values }\end{array}$ & Groups of subjects & Number & Mean value & $\begin{array}{l}\text { Standard } \\
\text { deviation }\end{array}$ & $\begin{array}{c}\text { Standard error } \\
\text { of the mean }\end{array}$ \\
\hline \multirow[t]{2}{*}{ Height } & Patients with chronic ALRH & 12 & 173.58 & 10.535 & 3.041 \\
\hline & Patients with seasonal ALRH & 18 & 172.44 & 7.664 & 1.806 \\
\hline \multirow[t]{2}{*}{ Weight } & Patients with chronic ALRH & 12 & 72.17 & 15.891 & 4.587 \\
\hline & Patients with seasonal ALRH & 18 & 73.28 & 12.256 & 2.889 \\
\hline \multirow[t]{2}{*}{ BMI } & Patients with chronic ALRH & 12 & 22.992 & 4.0383 & 1.1658 \\
\hline & Patients with seasonal ALRH & 18 & 24.650 & 4.042 & 0.952 \\
\hline \multirow[t]{2}{*}{ Age } & Patients with chronic ALRH & 12 & 24.25 & 3.415 & 0.986 \\
\hline & Patients with seasonal ALRH & 18 & 29.39 & 6.001 & 1.415 \\
\hline
\end{tabular}




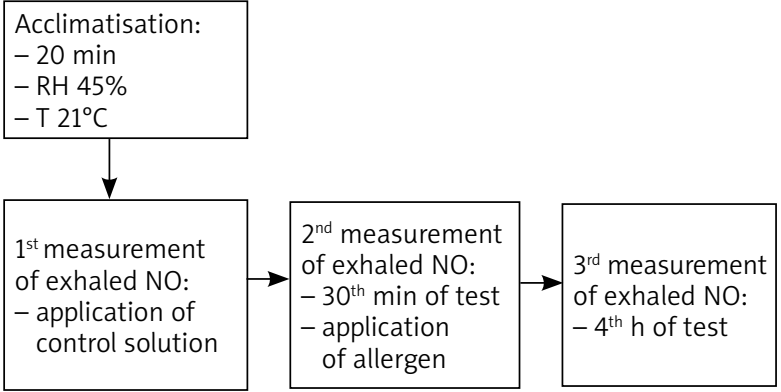

$R H$ - relative humidity, $T$ - air temperature.

Figure 1. Structure of the test measuring the concentration of nitric oxide exhaled from lower and upper airways

The measurement of $\mathrm{NO}$ in the air exhaled from the lower and upper airways was performed using an on-line method by means of Restricted Exhaled Breath (REB) in accordance with the guidelines issued by the American Thoracic Society Documents (ATS/ERS) [5]. The idea behind the technique is to separate the air exhaled from the nasal cavity into the mouth. The REB technique involves using the practice of breathing against resistance generated by positive pressure in a mouthpiece (5$20 \mathrm{~cm} \mathrm{H}_{2} \mathrm{O}$ ). This causes the soft palate, which covers the ostium of the nasopharynx, to rise. Thus, it prevents the air coming from the nasal cavities from affecting the result of the test. Therefore, each patient was breathing the air until the TLC level was reached while sitting. After that, using a mouthpiece with an individually adjusted resistance level, the patient took the longest possible breath out. The time of the breath out was approximately $6 \mathrm{~s}$. In measuring the concentration of NO in the air exhaled from the lower and upper airways, the patient stopped breathing to prevent gas from accumulating in the patient's nasal cavity [5]. The patient was sitting. The mouthpiece was placed in the correct position and at the correct height. Through the mouthpiece inserted in the patient's mouth, the patient was breathing the air in for 2-3 s until the total lung capacity was reached. This was followed by the patient taking a slow breath out [5]. The range of exhalation pressure was standardised at between 10 and $20 \mathrm{~cm} \mathrm{H}_{2} \mathrm{O}$. The measurement of $\mathrm{NO}$ in the exhaled air was analysed in ppb units (with a measurement range of 1-6000 ppb).

The measurement was performed by means of the HypAir FeNO nitric oxide analyser supplied by Medisoft. The device allows for controlling air flow at 50, 100, 150 and $350 \mathrm{ml} / \mathrm{s}$ and for determining the volume of air samples. The analyser comes with automatic quality control for measurement accuracy.

\section{Statistical analysis}

The statistical analysis of the concentration of NO in the air exhaled from the lower and upper airways in the

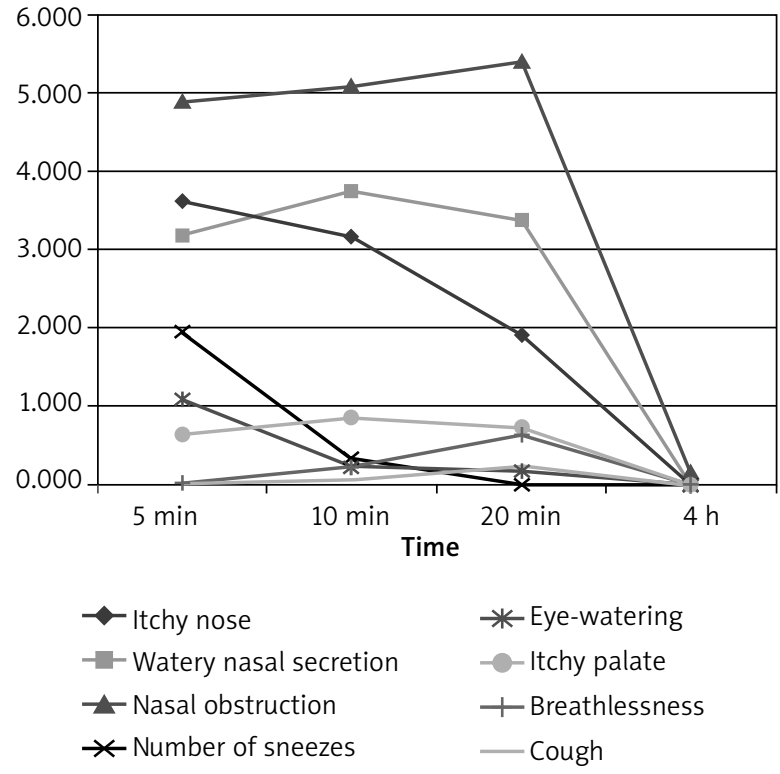

Figure 2. Changes, over time, of mean sensation levels as measured using a VAS in a nasal challenge test with an allergen, among patients with chronic ALRH

test and control groups was performed using the Statistica software. The following values were measured: the mean, standard deviation and the standard error of the mean. In order to determine the correlation strength value, Student's t-test was performed. Statistically significant results were defined for $p<0.05$.

The test was financed with a grant from the Ministry of Science and Higher Education (No. N402 520839). The study was approved by the Bioethics Committee at the Medical University of Warsaw (KB/79/2009).

\section{Results}

\section{Subjective techniques for measuring nasal patency: a visual analogue scale (VAS)}

Significant differences were identified in the average values of non-nasal complaints experienced by the patients, such as eye-watering, palate itching, breathlessness and coughing in the groups included in the study at the early phase of the allergic reaction (Figures 2, 3). The eye-watering symptom exacerbated mainly in the $5^{\text {th }}$ min of the test (standard deviation: patients with chronic ALRH: 2.26; patients with seasonal ALRH: 0.9430 $(p<0.05))$; palate itching in the $10^{\text {th }}$ min of the test (standard deviation: patients with chronic ALRH: 1.277; patients with seasonal ALRH: $0.831(p<0.05))$; breathlessness (standard deviation: patients with chronic ALRH: 1.373; patients with seasonal ALRH: $0.422(p<0.05))$; and coughing (standard deviation: patients with chronic ALRH: 0.48$)$ in the $20^{\text {th }}$ min of the test $\left.(p<0.05)\right)$ in the group of patients with allergic rhinitis versus the control group (Figures 2-4). 


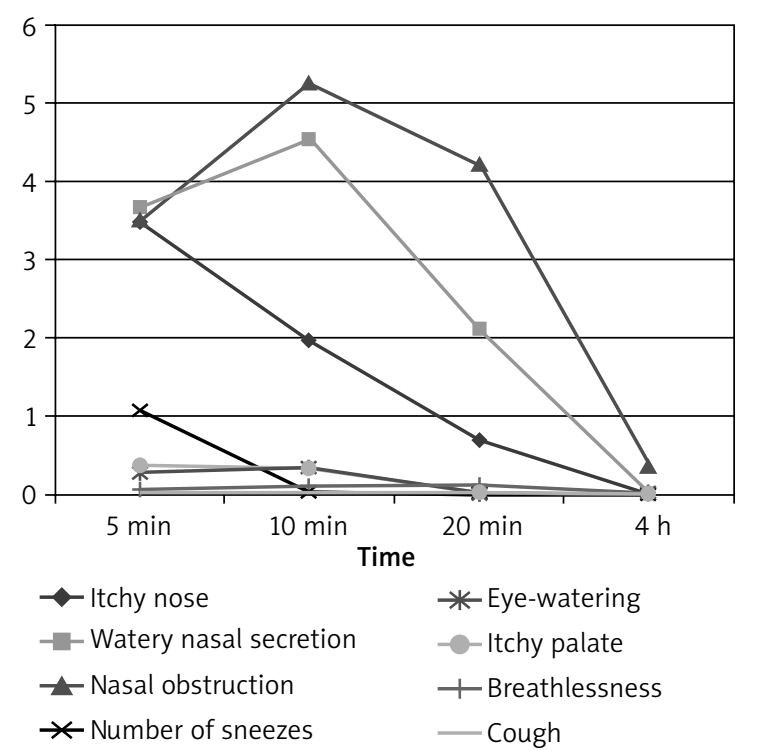

Figure 3. Changes, over time, of mean sensation levels as measured using a VAS in a nasal challenge test with an allergen, among patients with seasonal ALRH

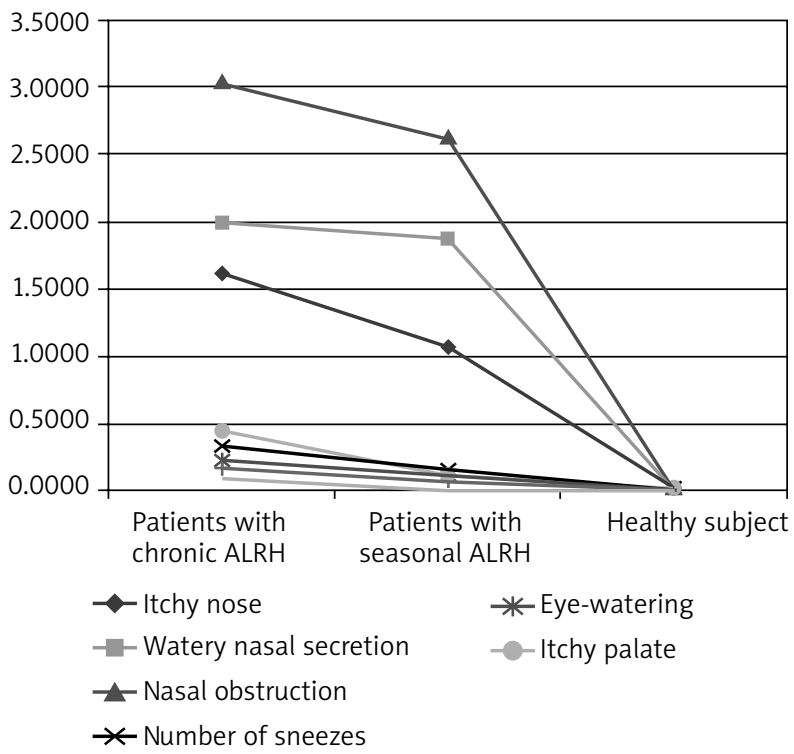

Figure 5. VAS scale in the nasal challenge test with an allergen

The analysis of subjective sensations using the VAS technique in a nasal challenge test with an allergen showed that the symptoms are experienced the most among the patients with chronic allergic rhinitis $(n=18)$ (Figure 5$)$.

No symptoms were identified in the control group $(n=30)$. The symptoms experienced the most in the test group were the following: nasal obstruction (average values: 3.03 for patients with chronic ALRH), 2.53 for those with seasonal ALRH); watery nasal secretion (average values: 1.984 for patients with chronic ALRH; 1.871 for patients with seasonal ALRH) and nasal itching (aver-

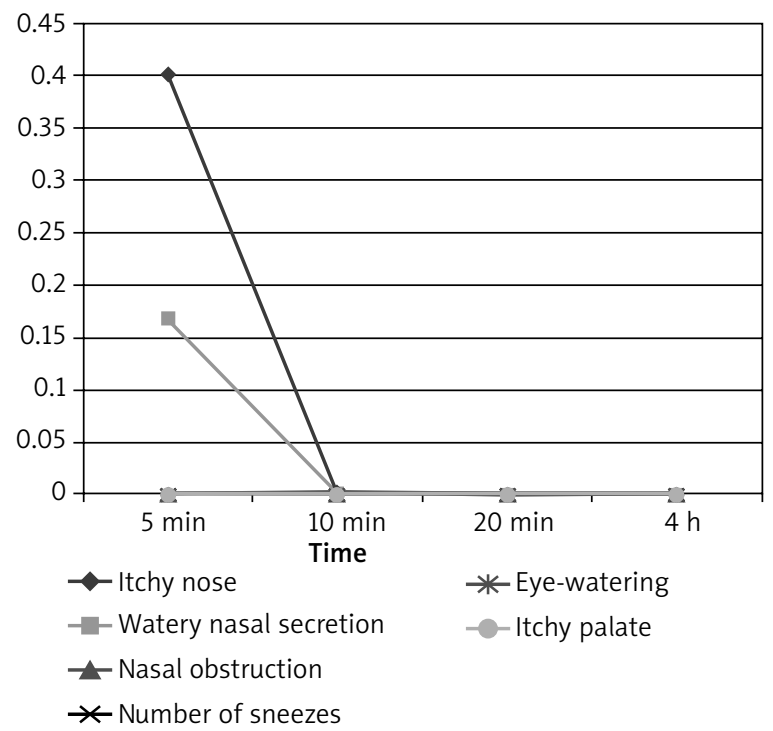

Figure 4. Changes, over time, of mean sensation levels as measured using a VAS in a nasal challenge test with an allergen, in the control group

age values: 1.613 for patients with chronic ALRH; 1.069 for those with seasonal ALRH). The following symptoms were experienced the least: coughing, breathlessness and eye-watering (Figure 5).

\section{Nitric oxide exhaled from the nose}

Before the application of the nasal challenge test with an allergen and in the $4^{\text {th }} \mathrm{h}$ of the test, the difference in the levels of NO in the air exhaled from the nose is, depending on the time of the test, between the test group and the control group, statistically significant $(p=0.005)$ (Table 2). The test shows that the level of NO exhaled from the upper airways is higher immediately before the application of the nasal challenge test with an allergen compared to the level in the $30^{\text {th }}$ min of the test (test group: average concentration level: $1173.03 \mathrm{ppb}$; control group: average concentration: $628.30 \mathrm{ppb}$ ) (Table 2).

In the case of patients with AR, the average concentration of NO in the air exhaled from the upper airways falls within the range of 397-1669 ppb. After the application of an allergen to all the subjects in the test group $(n=30)$ in the $30^{\text {th }} \mathrm{min}$, the concentration of NO in the exhaled air decreased ( $x=345 \pm 2.1 \mathrm{ppb}$ ). Subsequently, in the late phase (the $4^{\text {th }} \mathrm{h}$ of the test), the concentration of $\mathrm{NO}$ in the exhaled air increased (Figure 6).

The changes over time in the early phase $(p<0.05)$ and in the late allergic reaction $(p<0.05)$ were statistically significant.

\section{Nitric oxide exhaled from the lungs}

The difference in the concentration of $\mathrm{NO}$ exhaled from the lungs between the test group and the control 
Table 2. Level of nitric oxide exhaled from the nose, depending on the time of the test

\begin{tabular}{|c|c|c|c|c|}
\hline Parameter & & $\begin{array}{l}\text { Nitric oxide exhaled from } \\
\text { the nose before the nasal } \\
\text { challenge test }\end{array}$ & $\begin{array}{l}\text { Nitric oxide exhaled } \\
\text { from the nose } \\
30^{\text {th }} \mathrm{min} \text { of the test }\end{array}$ & $\begin{array}{l}\text { Nitric oxide exhaled } \\
\text { from the nose } \\
4^{\text {th }} \mathrm{h} \text { of the test }\end{array}$ \\
\hline \multirow[t]{2}{*}{ Mean } & Patient & 1137.03 & 879.53 & 1150.5 \\
\hline & Healthy subject & 628.3 & 604.63 & 655.83 \\
\hline \multirow{2}{*}{$\begin{array}{l}\text { Standard } \\
\text { deviation }\end{array}$} & Patient & 480.12 & 474.542 & 496.428 \\
\hline & Healthy subject & 363.95 & 315.069 & 387.782 \\
\hline \multirow{2}{*}{$\begin{array}{l}\text { Standard error } \\
\text { of the mean }\end{array}$} & Patient & 87.658 & 86.639 & 90.635 \\
\hline & Healthy subject & 66.448 & 57.523 & 70.799 \\
\hline \multirow{2}{*}{$\begin{array}{l}\text { Bilateral } \\
\text { significance }\end{array}$} & Patient & 0.00 & 0.011 & 0.00 \\
\hline & Healthy subject & - & - & - \\
\hline
\end{tabular}

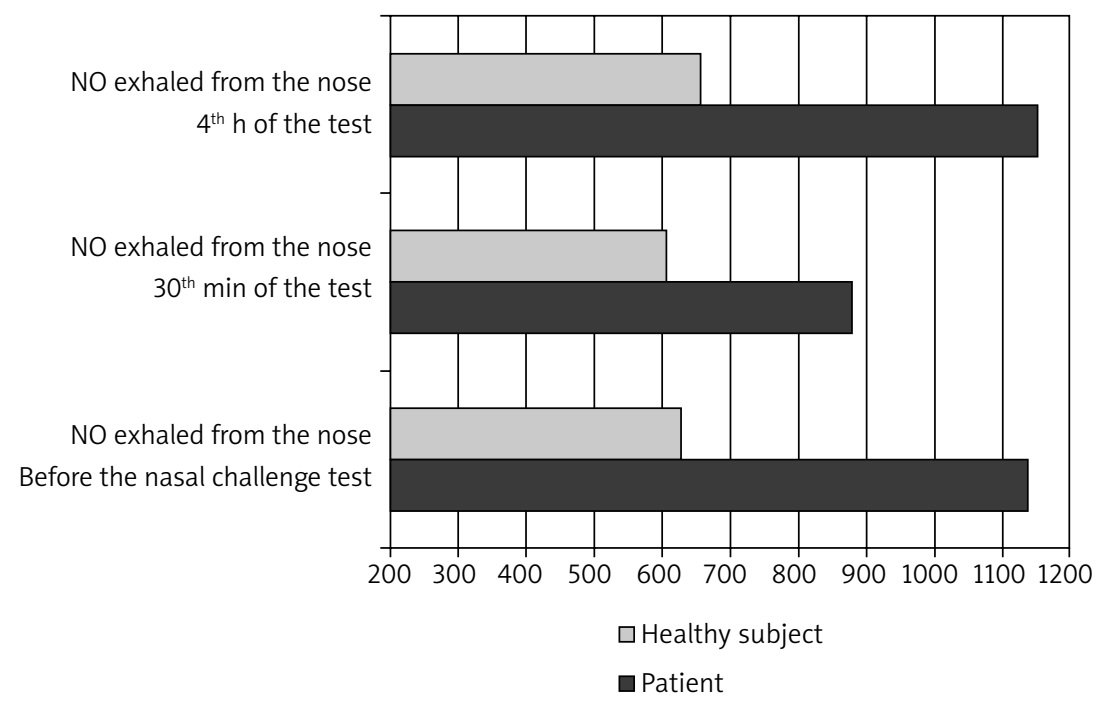

Figure 6. Level of nitric oxide exhaled from the nose, depending on the time of the test

group in the $4^{\text {th }} \mathrm{h}$ of the test is, depending on time of the test, statistically significant ( $p=0.045)$ (Table 3 ).

In the $4^{\text {th }} \mathrm{h}$ of the test, the concentration of $\mathrm{NO}$ in the air exhaled from the lungs in the control group decreased (average value: $17.73 \mathrm{ppb}$ ). In the test group, the concentration level remained almost unchanged (Figure 7 ). The average concentration of $\mathrm{NO}$ in the air exhaled from the lower airways ranged from 11 to $26 \mathrm{ppb}$.

An analysis of the concentration of NO in the air exhaled from the lower airways showed no statistically significant differences for the average change over time between the condition before the nasal challenge test with an allergen $(p=0.696)$ up to the $45^{\text {th }}$ min after the application of the allergen and the value in the late phase of the test $(p=0.217)$.

At the different points in time (i.e. before the nasal challenge test, in the $30^{\text {th }}$ min of the test and in the $4^{\text {th }} \mathrm{h}$ of the test), no statistically significant differences were identified in the concentration of NO in the air exhaled from the lungs between the test group and the control group ( $p=0.1411, p=0.06117$ and $p=0.04459$, respectively). In the case of the concentration of NO in the air exhaled from the nose, statistically significant differences were identified between the test group and the control group at the different points in time $(p<0.00001$, $p=0.01054$ and $p<0.00001$, respectively).

\section{Discussion}

According to Silkoff, a considerable advantage of NO is that measuring its levels is a non-invasive procedure [13]. The level of NO can be measured many times in both children and patients with obstructed air flow, where it is impossible to use more invasive techniques. Similar changes occurring in the case of the nasal challenge test recorded using the above inflammatory reaction test have been observed by many researchers. Research by Boot et al. showed a significant decrease, by 644 ppb 
Table 3. Level of nitric oxide exhaled from the lungs, depending on the time of the test

\begin{tabular}{|c|c|c|c|c|}
\hline Parameter & & $\begin{array}{l}\text { Nitric oxide exhaled } \\
\text { from the lungs before } \\
\text { the nasal challenge test }\end{array}$ & $\begin{array}{l}\text { Nitric oxide exhaled } \\
\text { from the lungs } \\
\text { in the } 30^{\text {th }} \mathrm{min}\end{array}$ & $\begin{array}{l}\text { Nitric oxide exhaled } \\
\text { from the lungs } \\
\text { in the } 4^{\text {th }} h\end{array}$ \\
\hline \multirow[t]{2}{*}{ Mean } & Patient & 22.17 & 22.5 & 23.13 \\
\hline & Healthy subject & 18.97 & 17.53 & 17.73 \\
\hline \multirow{2}{*}{$\begin{array}{l}\text { Standard } \\
\text { deviation }\end{array}$} & Patient & 9.896 & 12.367 & 12.428 \\
\hline & Healthy subject & 6.327 & 7.094 & 7.287 \\
\hline \multirow{2}{*}{$\begin{array}{l}\text { Standard error } \\
\text { of the mean }\end{array}$} & Patient & 1.807 & 2.258 & 2.269 \\
\hline & Healthy subject & 1.155 & 1.295 & 1.33 \\
\hline \multirow{2}{*}{$\begin{array}{l}\text { Bilateral } \\
\text { significance }\end{array}$} & Patient & 0.14 & 0.061 & 0.045 \\
\hline & Healthy subject & - & - & - \\
\hline
\end{tabular}

on average, in relation to the level before the nasal challenge test with an allergen [14]. Similarly, Korn et al. observed a 19.2\% decrease in relation to the level at the beginning of the test [15]. In our study, the concentration of $\mathrm{NO}$ in the air exhaled from the upper airways decreased (in the $30^{\text {th }}$ min of the test). Later, the concentration level increased (in the late phase of the test). This is undoubtedly caused by NO synthesis in the nasal sinuses. After the application of the nasal challenge test with an allergen, the nasal mucous membrane in the region of the nasal concha becomes swollen. As a consequence, the concentration of NO in the exhaled air decreases. Ziętkowski et al. confirm that the concentration of NO in the exhaled air decreases in patients with allergic rhinitis and increases in patients with the acute respiratory distress syndrome [16]. Research by the authors of this study also confirm the observations by Charitonov and Barnes, who proved that measuring the concentration of NO in the exhaled air is a useful method in assessing seasonal allergic rhinitis in patients of all age groups
[17]. In patients diagnosed with rhinitis (but suffering from asthma), the concentration of NO in the exhaled air increased to the values for active asthma. Moreover, this level increases with the patient's age [18-20]. In our study, the average concentration of NO in the exhaled air ranged from 11 to $26 \mathrm{ppb}$. The high levels of $\mathrm{NO}$ in the exhaled air are linked to a higher number of eosinophilia in the inflamed mucous membrane of the bronchia [18]. This is characteristic of ALRH and asthma. The levels of $\mathrm{NO}$ in the inhaled air decrease significantly as a result of anti-inflammatory treatment [18].

It can be concluded based on the test that NO is an indicator of the inflammation of the respiratory system. Research by the author of this study also confirms a statistically significant difference between the concentration of NO in the air exhaled from the lungs between the test group and the control group. This fact is very important in the differential diagnosis of allergies. According to Ziętkowski et al., monitoring the concentration of NO is a useful tool during observations of the

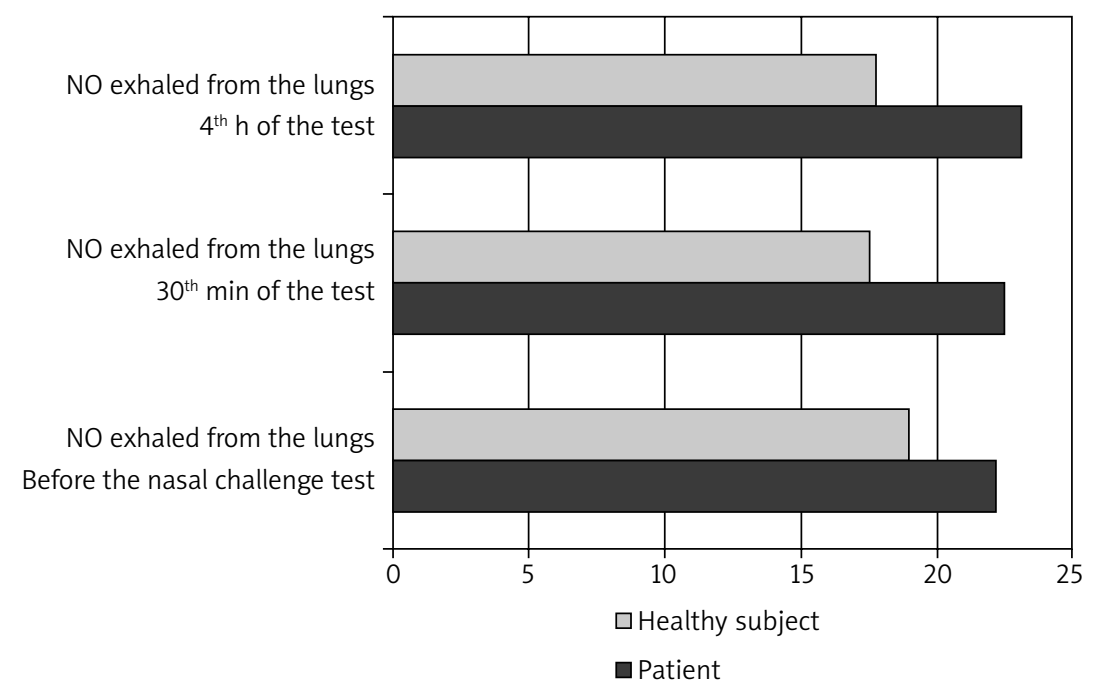

Figure 7. Level of nitric oxide exhaled from the lungs, depending on the time of the tes 
Table 4. Range of values at the average concentration of nitric oxide from the respiratory system [24]

\begin{tabular}{llll}
\hline \multicolumn{2}{l}{ Nitric oxide from the upper airways } & \multicolumn{2}{l}{ Nitric oxide from the lower airways } \\
\hline Adults & Clinical significance & Adults & Clinical significance \\
\hline$<100 \mathrm{ppb}$ & Ciliary dyskinesia or cystic fibrosis & $5-20 \mathrm{ppb}$ & Normal level \\
\hline$<450 \mathrm{ppb}$ & An indicator of nasal sinus ostial obstruction & $25-30 \mathrm{ppb}$ & Mild eosinophilic inflammation \\
\hline $450-900 \mathrm{ppb}$ & Normal level & $>50 \mathrm{ppb}$ & Severe eosinophilic inflammation of the airways \\
\hline$>900 \mathrm{ppb}$ & Inflammation of the nasal mucous membrane, including allergic inflammation, and sinus inflammation \\
\hline
\end{tabular}

inflammation of the lower airways in patients diagnosed with seasonal allergic rhinitis [18]. Frerie, too, confirmed that the concentration of $\mathrm{NO}$ in the exhaled air is a marker among inflammatory respiratory diseases [21]. In the case of patients diagnosed with allergic asthma, an increase in the concentration of NO in the exhaled air was observed [22, 23]. The subjects observed were adults and children. As a result of proving a correlation between NO and asthma, measuring the concentration of $\mathrm{NO}$ in the exhaled air may be a useful tool in asthma control assessment. Table 4 shows the range of values at the average concentration of NO from the respiratory system.

Numerous publications describe the role of NO in asthma patients who are active or passive smokers [25-27]. The concentration of NO in the exhaled air increases in patients with inflamed airways but not treated. In contrast, in the case of patients who have received medical treatment, the concentration of NO decreases [23]. Guidelines issued by the American Thoracic Society and research conducted by many researchers allow for determining the correct values of measurements of the concentration of NO in the exhaled air. As a result, the interpretation of the different results of the research is correct [5,28]. Taylor et al. confirmed that measurements of the concentration of NO in the exhaled air may be used to identify and monitor the activity of steroids in the treatment and diagnosis of respiratory diseases. They note the usefulness of measuring the concentration of NO in the exhaled air in the case of patients not administered inhaled steroids in the treatment of airway diseases [29]. In contrast, in the case of patients treated for asthma, the concentration of NO in the exhaled air is lower [30, 31]. In smoking asthma patients treated with steroids, the concentration of NO in the exhaled air decreases, which may affect the correlation between the exhaled NO and bronchial hyper-reactivity [32]. Moreover, many publications describe correlations between the exhaled NO and bronchial hyper-reactivity in adult patients with asthma, children with allergic asthma [32-35], antiinflammatory treatment of asthma, treatment of asthma with steroids, and inflamed airways [17, 29, 32]. Schneider et al. carried out research to identify the level of the exhaled NO which excludes asthma in patients diagnosed with obstructive airway disease for the first time.
According to Scadding, eosinophilic airway inflammation is confirmed if the concentration of $\mathrm{NO}$ in the exhaled air is greater than $35 \mathrm{ppb}$ [24]. Schneider states that asthma could be ruled in with FENO > $46 \mathrm{ppb}$ [36]. However, Turner says that "excessive" NO in patients diagnosed with asthma is usually released by the lower airway epithelium, where the exhaled gas probably determines the development of eosinophilic inflammation. At the same time, the same publications note that NO may be used to evaluate the course of this condition [28, 37-40]. In healthy smoking subjects, a lower concentration of $\mathrm{NO}$ in the exhaled air was observed [32, 33, 41]. However, none of the publications contains information on what concentration of $\mathrm{NO}$ in the exhaled air triggers airway inflammation in healthy subjects [32, 33, 41]. The concentration of NO in the air exhaled from the upper airways in healthy smoking subjects is not standardised either.

No research into the levels of NO in the exhaled air confirms any correlation between age and the concentration of the exhaled gas in adults. The case is different with children, as the concentration of $\mathrm{NO}$ in the exhaled air increases with age [5]. If a patient has a spirometry test before measuring the NO concentration level, the measurement is distorted. Therefore, a report issued by the American Thoracic Society recommends that the concentration of NO in the exhaled air should be measured before taking spirometry tests [5]. In addition, the report specifies factors that distort such measurements. These include: drinking and eating at least $1 \mathrm{~h}$ before the measurement (nitrates, nitrites and liquids temporarily change the FENO level); virus infections (these increase the level of the exhaled NO in asthma patients); and HIV infection (this decreases the level of the exhaled NO). Smoking is described in the literature fairly superficially. It has been proved that the concentration of NO in the exhaled air is lower in smoking healthy subjects and higher in smoking asthma patients. If a patient is on medication, it is recommended that the patient should not take any pharmaceuticals before NO concentration measurements, if possible. Otherwise, all the pharmaceuticals taken by the patient should be recorded in the test report. Age and gender are among the factors that distort the measured levels of exhaled nitric oxide. The impact of pregnancy, body size (height/weight) and the menstrual cycle has not been determined, so these must 
be noted in the test report. As physical exercise may reduce the concentration of $\mathrm{NO}$ in the exhaled air, the patient should not do any exercise at least $1 \mathrm{~h}$ before taking the measurements [5]. A group of Slovak scientists has observed that the concentration of NO in the exhaled air is affected by a large number of different factors. These include: gender, medication, the menstrual cycle and metabolism [21]. Therefore, before taking the measurements, the patient's age and gender should also be checked.

Our research confirmed the results of research published in the literature with regard to the concentration of NO in the air exhaled from the upper or lower airways. Research by us and other authors shows that the concentration of NO in the air exhaled from the upper airways is significantly higher than the concentration of NO in the air exhaled from the lower airways [42-44], which is linked to NO synthesis in the nasal sinuses. Measuring the concentration of NO in the exhaled air in the case of patients with allergic rhinitis is a useful tool for noninvasive assessment of the airway inflammation process. Measurements of the concentration of $\mathrm{NO}$ in the exhaled air may be useful in evaluating the effectiveness of specific immunotherapy and in monitoring anti-inflammatory treatment processes. An international group of experts on clinical and basic research into asthma and/or nitric oxide, pulmonology, allergology, physiology and paediatrics claims that the advances in technology and the standardisation of simple eNO measurement tests allow NO to be used as a biomarker that opens a new dimension in the area of traditional tests used in the diagnosis and monitoring of respiratory diseases. Guidelines issued by experts with regard to interpreting eNO measurements are expected to increase the application of the measurements in clinical research [45].

\section{Conclusions}

During nasal allergen provocation tests (NAPT), the concentration of NO in the air exhaled from the upper airways decreased in the $30^{\text {th }}$ min and increased in the late phase ( $4^{\text {th }} \mathrm{h}$ of the test), which is probably as a result of nasal oedema just after the NAPT. In the test group, the concentration of NO in the air exhaled from the lower airways remained unchanged at each time point during the NAPT.

\section{Conflict of interest}

The authors declare no conflict of interest.

\section{References}

1. Alobid I, Benitez P, Valero A, et al. Oral and intranasal steroid treatments improve nasal patency and paradoxically increase nasal nitric oxide in patients with severe nasal polyposis. Rhinology 2012; 50: 171-7.
2. Furgchott R, Zawadzki JV. The obligatory role of endothelial cells in the relaxation of arterial smooth muscle by acetylcholine. Nature 1980; 288: 373-6.

3. Alving K, Weitzberg E, Lundberg JM. Increased amount of nitric oxide in exhaled air of asthmatics. Eur Respir J 1993; 6: 1368-70.

4. Lundberg JO. Airborne nitric oxide: inflammatory marker and aerocrine messenger in man. Acta Physiol Scand (Suppl.) 1996; 633: 1-27.

5. ATS/ERS. Recommendations for standardized procedures for the online and offline measurement of exhaled lower respiratory nitric oxide. Am J Respir Crit Care Med 2005; 171: 912-30.

6. Qian W, Djupesland PG, Chatkin JM, et al. Aspiration flow optimized for nasal nitric oxide measurement. Rhinology 1999; 37: 61-5.

7. Wright AL, Holberg Cl, Martinez FD, et al. Epidemiology of physician-diagnosed allergic rhinitis in childhood. Pediatrics 1994; 94: 895-2.

8. Settipane RJ, Hagy GW, Settipane GA. Long-term risk factors for developing asthma and allergic rhinitis: 23-year follow-up study of college students. Allergy Proc 1994; 15: 21-6.

9. Rutkowski K, Sowa P, Rutkowska-Talipska J, et al. Allergic diseases: the price of civilisational progress. Postep Derm Alergol 2014; 31: 77-83.

10. Foresi A, Leone C, Pelucchi A, et al. Eosinophils, mast cells and basophils in induced sputum from patients with seasonal allergic rhinitis and perennial asthma: relationship to methacholine responsiveness. J Allergy Clin Immunol 1997; 100: 58-63.

11. Olin AC, Andersson M, Granung G, et al. Atopic subjects without respiratory symptoms have normal exhaled NO. Am J Respir Crit Care Med 2001; 163: 46.

12. Gratziou C, Lignos M, Dassiou M, et al. Influence of atopy on exhaled nitric oxide in patients with stable asthma and rhinitis. Eur Respir J 1999; 14: 897-901.

13. Silkoff PE. Noninvasive measurement of airway inflammation using exhaled nitric oxide and induced sputum. Chest Clin Med 2000; 21: 345-60.

14. Boot JD, Kam ML, Mascelli MA, et al. Nasal nitric oxide: longitudinal reproducibility and the effects of a nasal allergen challenge in patirnets with allergic rhinitis. Allergy 2007; 62: 378-84.

15. Korn S, Beier J, Heilmann C, et al. Discrepant nasal and bronchial nitric oxide kinetics during early and late phase allergic reactions. Respirat Med 2005; 99: 1595-9.

16. Ziętkowski Z, Ziętkowska E, Bodzenta-Łukaszyk A. Tlenek azotu w powietrzu wydychanym - praktyczne zasady wykonywania oraz interpretacji wyników. Alergia 2010; 1: 29-33.

17. Charitonow SA, Barnes PJ. Does exhaled nitric oxide reflect asthma control. Am J Respir Crit Care Med 2001; 164: 727-8.

18. Ziętkowski Z, Bodzenta-Łukaszyk A, Tomasiak MM. Tlenek azotu w powietrzu wydychanym $u$ chorych na alergiczny sezonowy nieżyt nosa. Alergia Astma Immunol 2004; 9: 93-8.

19. Bożek A, Filipowska-Grońska A, Weryńska-Kalemba M, et al. Measurements of nitric oxide in patients with seasonal allergic rhinitis in the different age groups. Postep Derm Alergol 2010; 27: 96-100.

20.Samoliński B, Sybilski A. Znaczenie stanów zapalnych błony śluzowej nosa w astmie oskrzelowej. Wspótistnienie ANN i astmy oskrzelowej. Alergia Astma Immunol 2007; 12: 7-14.

21. Antosova M, Bencova, Psenkova, et al. Exhaled nitric oxide - circadian variations in healthy subjects. Euro J Med Res 2009; 14: 6-8. 
22. Kalicki B, Jung A, Grad A, et al. Czy oznaczanie stężenia tlenku azotu (NO) i IL-4 w kondensacie powietrza wydychanego może być wykorzystane w ocenie zaostrzeń i leczeniu astmy u dzieci? Alergologia Info 2008; 3: 112-9.

23. Chmielewska-Szewczyk D. Diagnostyka astmy u dzieci. Alergia 2007; 2: 4-8.

24. Scadding G, Scadding GK. Update on the use of nitric as a non-invasive measure of airways inflammation. Rhinology 2009; 47: 115-20.

25. Nadif R, Matran R, Maccario J, et al. Passive and active smoking and exhaled nitric oxide levels according to asthma and atopy in adults. Ann Allergy Asthma Immunol 2010; 104: 385-93.

26.Zietkowski Z, Bodzenta-Łukaszyk A, Tomasiak MM, et al. Comparison of measurement of nitric oxide in exhaled air from the conventional studies in steroid-naive asthmatic patients. J Clin Immunol Investig Allergol 2006; 16: 239-46.

27. Reid DW, Johns DP, Feltis B, et al. Nitric oxide in exhaled air reflects airway hyperresponsiveness and disease caused by inhaled corticosteroids in adult asthmatic patients. Respirology 2003; 8: 479-86.

28.Ziętkowski Z, Ziętkowska E, Bodzenta-Łukaszyk A. Kliniczne znaczenie pomiarów stężenia tlenku azotu w powietrzu wydychanym w chorobach układu oddechowego. Alergia Astma Immunol 2009; 14: 215-22.

29. Taylor DR, Pijnenburg MW, Smith AD, et al. Exhaled nitric oxide measurements: clinical application and interpretation. Thorax 2006; 61: 817-27.

30. Michils A, Louis R, Peche R, et al. Exhaled nitric oxide as a marker of asthma control in smoking patients. Eur Respir J 2009; 33: 1295-301.

31. Verleden GM, Dupont LJ, Verpeut AC, et al. Effect of cigarette smoking on exhaled nitric oxide levels in patients with mild asthma. Chest 1999; 116: 59-64.

32. Dupont LJ, Rochette F, Demedts MG, et al. Exhaled nitric oxide correlates with airway hyperresponsiveness in steroidnaive patients with mild asthma. Am J Med Respir Crit Care 1998; 157: 894-8.

33. Laoudi Y, Nikasinovic L, Sahraoui F, et al. Passive smoking is a major determinant of exhaled nitric oxide levels in allergic asthmatic children. Allergy 2010; 65: 491-7.

34. Tworek D, Bocheńska-Marciniak M, Kupczyk M, et al. Brak korelacji między stężeniem tlenku azotu w powietrzu wydychanym (eNO) a klinicznymi wskaźnikami nasilenia choroby i jakością życia w grupie chorych na lekką i umiarkowaną astmę oskrzelową. Pneumonol Alergol Pol 2006; 74: 391-5.

35. Gelb AF, George SC, Silkoff PE, et al. Central and peripheral airway/alveolar sites of exhaled nitric oxide in acute astma. Thorax 2010; 65: 619-25.

36. Schneider A, Tilemann L, Schermer T, et al. Diagnosing asthma in general practice with portable exhaled nitric oxide measurement. Respir Res 2009; 3: 10-5.

37. Turner S. Exhaled nitric oxide in the diagnosis and management of asthma. Curr Opin Allergy Clin Immunol 2008; 8: 70-6.

38. Payne DN. Nitric oxide in allergic airway inflammation. Curr Opin Allergy Clin Immunol 2003; 3: 133-7.

39. Rouhos A, Ekroos H, Karjalainen J, et al. Smoking attenuates increase in exhaled nitric oxide in atopic but not in nonatopic young adults with asthma. Int Arch Allergy Immunol 2010; 152: 226-32.

40.Oh MJ, Lee JY, BJ Lee, et al. Exhaled nitric oxide measurement is useful for the exclusion of nonasthmatic eosinophilic bronchitis in patients with chronic cough. Chest 2008; 134: 990-5.

41. Robbins RA, T Millatmal, Lassi K, et al. Smokin cessation is associated with an increase in exhaled nitric oxide. Chest 1997; 112: 313-8.

42. Palm JP, Graf P, Lundberg JO, et al. Characterization of exhaled nitric oxide: introducing a new reproducible method for nasal nitric oxide measurements. Eur Respir J 2000; 16: 236-41.

43. Tornberg DC, Marteus H, Schedin U, et al. Nasal and oral contribution to inhaled and exhaled nitric oxide: a study in tracheotomized patients. Eur Respir J 2002; 19: 859-64.

44. Weschta M, Deutschle T, Riechelmann H. Nasal fractional exhaled nitric oxide analysis with a novel hand-held device. Rhinology 2008; 46: 23-7.

45. Dweik RA, Boggs PB, Erzurum SC, et al. An official ATS clinical practice guideline: interpretation of exhaled nitric oxide levels (FENO) for clinical applications. Am J Respir Crit Care Med 2011; 184: 602-15. 